\title{
Poultry manure induce biotransformation of hexavalent chromium in soil
}

\author{
Sunitha Rangasamy ${ }^{1^{*}}$, Bharani Alagirisamy ${ }^{1}$ and Mahimairaja Santiago ${ }^{1}$ \\ ${ }^{I}$ Department of Environmental Science, Agriculture College and Research Institute, Tamil Nadu Agricultural \\ University, Coimbatore, Tamil Nadu 641 003, India.
}

\begin{abstract}
Chromium (Cr) in the trivalent form (Cr III) is an important component of a balanced human and animal diet and its deficiency causes disturbance to the glucose and lipid metabolism in humans and animals. In contrast, hexavalent $\mathrm{Cr}$ (Cr VI) is a highly toxic carcinogen and may cause death to animals and humans if ingested in large doses. Recently, concern about $\mathrm{Cr}$ as an environmental pollutant has been escalating due to its build up to toxic levels in the environment as a result of various industrial and agricultural activities. In the present study, the hexavalent chromium was reduced into trivalent chromium from chromium contaminated $\left(300 \mu \mathrm{g} \mathrm{g}^{-1}\right)$ soil. In the presence of organic amendments (poultry manure) and microbial inoculants (Pseudomonas fluorescens and Trichoderma viride) the chromium (VI) reduction was observed in maximum in the poultry manure treatment (91\%) whereas poultry manure with Pseudomonas fluorescens reduced the hexavalent chromium up to $90 \%$.
\end{abstract}

Key Words: Bioremediation, Cr (VI), Poultry manure, Trichoderma viride, Pseudomonas fluorescens, detoxification

\section{Introduction}

Increasing levels of heavy metals in the environment pose serious threats to water quality, soil eco system, human health and living organisms (An et al. 2001; Wingenfelder et al. 2005; Vinodhini and Narayanan, 2008). Cr, Ni, Zn, Cu and $\mathrm{Cd}$ are considered as priority metals from the point of view of potential health hazards to human. Hexavalent chromium has high toxicity for humans and animals (McBride 1994; Ayuso et al. 2003; Babel and Opiso, 2007) and commonly interferes with beneficial use of effluents for irrigation and industrial applications. They are also the groundwater contaminants at industrial installations (Mier et al. 2001; Malakootian et al. 2009). In epidemiological studies, an association has been found between exposure to $\mathrm{Cr}(\mathrm{VI})$ by the inhalation and lung cancer. IARC has classified chromium (VI) as a Group 1 (human carcinogen) (WHO 2004). Some cities in Iran have high amount of hexavalent chromium content in ground water resources.

In recent year's contamination of the environment by $\mathrm{Cr}$, especially hexavalent $\mathrm{Cr}$ has become a major area of concern. Dissemination of $\mathrm{Cr}$ in the environment is due to many different industries including metallurgical, electroplating, paints and pigments, tanning, wood preservation, $\mathrm{Cr}$ chemicals production and pulp and paper industries. Often, wastes from such industries (e.g., sludge, fly ash, slag, etc.) are used as a fill material at numerous locations to reclaim marshlands, tank dikes, and backfill at sites following demolition (Salunkhe et al., 1998). At many such sites, leaching and seepage of $\mathrm{Cr}$ (VI) from the soils into the groundwater poses a considerable health hazard. The tanning industry is a large contributor of $\mathrm{Cr}$ pollution to water resources. Chandra et al. (1997) estimated that in India alone about 2000 to 3200 tonnes of elemental Cr escape into the environment annually from the tanning industries with a $\mathrm{Cr}$ concentration ranging between 2000 and $5000 \mathrm{mg} \mathrm{L}^{-1}$ in the effluent compared to the recommended permissible limit of $2 \mathrm{mg} \mathrm{L}^{-1}$.

Conventional method for industrial effluent treatment is physicochemical treatment including ion exchange, vacuum evaporation, solvent extraction and membrane technologies (Applegate 1984; Sengupta and Clifford 1986; Kentish and Stevens 2001). Among these, ion exchange is one of the most effective and economical methods (Tran et al. 1999; Nameni et al. 2008). Use of various sorbents such as bentonite (Zvinowanda et al. 2009), chitosan (Jha et al. 1988), perlite (Mathialagan and Viraraghavan 2002), coal (Karabulat et al. 2000) and activated carbon (Fan and Anderson 2005; Gueu et al., 2007) have been reported for the removal of heavy metals including chromate from aqueous solutions.

Inexpensive remediation technologies are needed for $\mathrm{Cr}(\mathrm{VI})$ by reduction or biotransformation is a promising approach. In the present study, we studied the detoxification of $\mathrm{Cr}(\mathrm{VI})$ from the contaminated soil using poultry manure, earthworm and microbe. The earthworm population and its survival were examined. 


\section{Materials and Methods}

A pot experiment was conducted to examine the effect of poultry manure, Earthworms (Eisenia foetida and Eudrilus eugeniae) and microorganisms (Pseudomonas fluorescens and Trichoderma viride) in reducing the toxic Cr (VI) in soil.

Bulk soil samples were collected at 0 to $30 \mathrm{~cm}$ depth from TNAU (Farm Eastern Block Field No. 37), Coimbatore. The samples were air dried at $25^{\circ} \mathrm{C}$ and sieved $(<2 \mathrm{~mm})$ and the soil was used in this study. Syntax pots with a capacity of $1500 \mathrm{~cm}^{3}$ were used. One $\mathrm{kg}$ of soil was weighed and transferred into each pot. The soil was added with $\mathrm{Cr}$ (VI) at a rate equivalent to $300 \mathrm{mg} \mathrm{kg}^{-1}$ by using a standard solution of $\mathrm{K}_{2} \mathrm{Cr}_{2} \mathrm{O}_{7}$. The $\mathrm{Cr}$ solution was added and thoroughly mixed with the soil. After a day of equilibration, poultry manure (@10 $\left.10 \mathrm{tha}^{-1}\right)$ was added in as per the treatment schedule and uniformly mixed. The rate of application of poultry manure was based on TNAU recommendation (Crop production guide, 2009). The microbial strains viz., Pseudomonas fluorescens and Trichoderma viride were introduced into the soil (@2.5 kg ha ${ }^{-1}$ ). After 3 days of incubation, uniform size ten number of earthworm species $(20 \mathrm{~cm}$ length of Eudrilus eugenia and $10 \mathrm{~cm}$ length of Eisenia foetida which was $0.2 \mathrm{~g}$ and $1 \mathrm{~g}$ each respectively) were introduced into the pots and incubated at field capacity moisture $\left(0.52 \mathrm{~g} \mathrm{~g}^{-1}\right)$. The moisture loss was compensated by adding distilled water once in three days and the moisture content was maintained throughout the experimental period. At fortnight intervals, soil samples were removed from each pot and analysed for $\mathrm{Cr}$ (VI).

Treatment details

$\mathrm{T}_{1}$ : Control - Soil* (No amendment)

$\mathrm{T}_{2}$ : Soil* + Poultry manure

$\mathrm{T}_{3}$ : Soil ${ }^{*}+$ Poultry manure + Eisenia foetida

$\mathrm{T}_{4}$ : Soil ${ }^{*}+$ Poultry manure + Eudrilus eugeniae

$\mathrm{T}_{5}:$ Soil*+ Pseudomonas fluorescens

$\mathrm{T}_{6} \quad$ : Soil ${ }^{*}+$ Poultry manure + Pseudomonas fluorescens

$\mathrm{T}_{7} \quad$ : Soil ${ }^{*}+$ Poultry manure + Pseudomonas fluorescens + Eisenia foetida

$\mathrm{T}_{8} \quad$ : Soil $*+$ Poultry manure + Pseudomonas fluorescens + Eudrilus eugeniae

$\mathrm{T}_{9} \quad$ : Soil $^{*}+$ Trichoderma viride

$\mathrm{T}_{10}$ : Soil* + Poultry manure + Trichoderma viride

$\mathrm{T}_{11}$ : Soil ${ }^{*}+$ Poultry manure + Trichoderma viride + Eisenia foetida

$\mathrm{T}_{12}$ : Soil* + Poultry manure + Trichoderma viride + Eudrilus eugeniae

Soil * - Soil spiked with $300 \mathrm{mg}$ Cr (VI) kg ${ }^{-1}$

The Cation Exchange Capacity of the soil sample was determined by neutral ammonium acetate solution method (Jackson, 1973).

The $\mathrm{pH}$ and the electrical conductivity of the samples (EC) were measured using a combined electrode pH meter and Conductivity Bridge, respectively (Jackson, 1973). Total organic carbon content of the samples was determined by the wet digestion method (Walkley and Black, 1934).

The concentration of $\mathrm{Cr}$ (VI) (water soluble fraction) was determined as per the method outlined by USEPA (1979b).

\section{Results and Discussion}

Large amount of animal and poultry manure / farmyard manure (FYM) and organic amendments are used in agriculture for sustaining soil health. Along with these are also helpful in remediating the heavy metal contaminated soil. It has been widely reported that the organic amendments are capable of reducing toxic $\mathrm{Cr}$ (VI) to $\mathrm{Cr}$ (III), as they form a source of electron donor. The organic amendments also immobilize Cr mainly by forming organic-metallic complexes (Harrison, 1992). Therefore, a series of laboratory experiment was conducted to evaluate poultry manure and microbial cultures for developing a bioremediation technology for $\mathrm{Cr}$ contaminated soil. Initially the soil and poultry manure was characterised and data presented in Table 1.

The effect of poultry manure, microbial strains ( $P$. fluorescens and $T$. viride) and earthworms (Eisenia foetida and Eudrilus eugeniae) on reduction of Cr VI is presented in Table 2. Initially Cr VI (300 mg kg-1) was taken for treatment along with poultry manure, microbial strains and earthworms. From the initial day to 60 days of incubation, the Cr VI concentration range was drastically reduced from 226 to $298 \mathrm{mg} \mathrm{kg}^{-1}$ to 25 to $224 \mathrm{mg}$ $\mathrm{kg}^{-1}$. Although in control soil $\left(\mathrm{T}_{1}\right)$ the concentration was significantly decreased from 15 to 60 days of incubation. Application of poultry manure alone $\left(\mathrm{T}_{2}\right)$ markedly reduce the Cr VI concentration $\left(25 \mathrm{mg} \mathrm{kg}^{-1}\right)$ at all days of incubation. The percentage of $\mathrm{Cr}$ VI reduction on various amendments is given in Figure 1 . The higher rate of $\mathrm{Cr}$ VI reduction was seen not only treating with poultry manure but also along with other amendments $\left(\mathrm{T}_{3}\right.$ and $\left.\mathrm{T}_{4}\right)$. Among the worms, Eisenia foetida was found relatively more effective in reducing the $\mathrm{Cr}$ VI than Eudrilus eugeniae were seen at all days of incubation. Mortality of the earthworms was observed due to $\mathrm{Cr}$ (VI) toxicity within few days of introduction into the soil, though the earthworm effect on $\mathrm{Cr}$ (VI) 
reduction has not been reflected significantly. Therefore, they have been eliminated from further studies. Among the all treatments the poultry manure amended with Eisenia foetida soil treatment $\left(\mathrm{T}_{3}\right)$ was reduced the chromium up to 24 per cent in all the incubation period (15 days to 60 days) interval followed by Poultry manure with Pseudomonas fluorescens $\left(\mathrm{T}_{6}\right)$ and poultry manure alone $\left(\mathrm{T}_{2}\right)$ treatment. The maximum reduction of $\mathrm{Cr}$ VI $(90.7 \%)$ occurred at the end of 60 days due to the application of poultry manure and $P$. fluorescens $\left(\mathrm{T}_{2}\right)$. Reduction of $\mathrm{Cr}(\mathrm{VI})$ to $\mathrm{Cr}$ (III) in soils has often been found to be rapid and reaching the maximum within a relatively short time (Ross et al., 1981). The supply of carbons and protons, and stimulation of microorganisms that are considered to be the major factors enhancing the reduction of $\mathrm{Cr}$ (VI) to $\mathrm{Cr}$ (III) (Losi et al., 1994; Bolan et al., 2003). The result corroborates with the findings of Bolan et al. 2003. Losi and co workers (1994) have shown that the addition of manure compost caused a larger increase in the biological reduction than the chemical reduction of $\mathrm{Cr}(\mathrm{VI})$, which suggests that the supply of microorganisms is more important than the supply of organic carbon.

It has been shown that the addition of microbial strains (P. fluorescens / T. viride) alone resulted in marked reduction (66.3 to $75.7 \%$ ) in Cr VI (Figure 1). Only a small increase in the reduction of Cr (VI) was observed when P. fluorescens alone applied along with organic amendments. Losi and co workers (1994) reported that the addition of organic manure compost increased $\mathrm{Cr}$ (VI) reduction both under sterile (i.e., abiotic) and non-sterile (i.e., biotic) conditions. However, Bolan and co workers (2003) showed that the treatment with manure caused a large increase in biotic than abiotic $\mathrm{Cr}(\mathrm{VI})$ reduction. This may suggest that the supply of microorganisms was more important than the supply of organic carbon in enhancing the reduction of $\mathrm{Cr}(\mathrm{VI})$ with the addition of organic compost.

The effect of poultry manure, microbial strains and earthworms on soil organic carbon (SOC) content is presented in Table 3. Initially the SOC ranged from 9.6 to $18.2 \mathrm{~g} \mathrm{~kg}^{-1}$. Soil with the application of $P$. fluorescens alone recorded the lowest value of SOC; whereas, the soil with the application of poultry manure $\left(\mathrm{T}_{2}\right)$ had the highest amount of SOC. Irrespective of treatments, the SOC was found decreased gradually during the incubation. At the end of 60 days of incubation, the SOC ranged between 3.2 and $6.7 \mathrm{~g} \mathrm{~kg}^{-1}$. Due to microbial respiration and decomposition of soil organic matter (SOM), the SOC was found reduced gradually after the treatment. However, the combined effect of poultry manure, earthworms and microbial strain has not produced any clear cut trend on SOC content. There was a significant linear relationship between the extent of $\mathrm{Cr}$ (VI) reduction and DOC. DOC has been identified to facilitate the reduction of $\mathrm{Cr}$ (VI) to $\mathrm{Cr}$ (III) in soils (Jardine et al., 1999; Nakayasu et al., 1999; Bolan et al., 2003). Theoretically, it is estimated that $1.00 \mathrm{mg}$ of organic carbon is required to cause a reduction of $5.78 \mathrm{mg} \mathrm{Cr}$ (VI) based on the following reaction (Adriano, 2001).

$$
3 \mathrm{CH}_{2} \mathrm{O} \text { (organic matter) }+2 \mathrm{Cr}_{2} \mathrm{O}_{7}+16 \mathrm{H}^{+} \rightarrow 4 \mathrm{Cr}^{3+}+3 \mathrm{CO}_{2}+11 \mathrm{H}_{2} \mathrm{O}
$$

\section{Conclusions}

Addition of organic amendments with or without microbial strains and earthworms resulted in a significant reduction of $\mathrm{Cr}(\mathrm{VI})$ in soil. Since mortality of earthworms were found due to $\mathrm{Cr}$ (VI) toxicity within few days of introduction into the soil, the effect of earthworm on $\mathrm{Cr}$ (VI) reduction has not been reflected significantly. Application of organic amendments increases the soil $\mathrm{pH}$ which directly increases the reduction of $\mathrm{Cr}(\mathrm{VI})$. A maximum reduction of $\mathrm{Cr} \mathrm{VI}(90.7 \%)$ occurred at the end of 60 days due to the application of poultry manure and P. fluorescens. Addition of microbial strains (P. fluorescens / T. viride) alone resulted in marked reduction (66.3 to $75.7 \%$ ) in $\mathrm{Cr}$ (VI). The large amount of hexavalent chromium was detoxified due to application of poultry manure and there by the crops can uptake the nutrients supplied by these amendments. These particular amendments can be recommended for hexavalent chromium contaminated soil. Our findings indicate that the addition of organic amendments to $\mathrm{Cr}$ (VI) contaminated mineral soil enhanced the reduction of $\mathrm{Cr}$ (VI) to $\mathrm{Cr}$ (III), thereby reducing the bioavailability of $\mathrm{Cr}$ for plant uptake.

\section{Acknowledgements}

India.

This work was financially supported by Department of Science and Technology (DST), Government of

\section{References}

[1]. Adriano D C, 2001. Trace Elements in Terrestrial Environments: Biogeochemistry, bioavailability and risks of metals. 2nd ed. Springer, New York

[2]. An H K, Park B Y, Kim D S, 2001. Crab shell for the removal of heavy metals from aqueous solution. Water Res., 35 (15): $3551-$ 3556

[3]. Applegate L E, 1984. Membrane separation processes. Chem. Eng. J., 91: 64 - 69

[4]. Babel S, Opiso E M, 2007. Removal of Cr from synthetic wastewater by sorption into volcanic ash soil. Int. J. Environ. Sci. Tech, 4 (1): $99-107$

[5]. Bolan N S, Adriano D C, Natesan R, Koo B J, 2003. Effects of organic amendments on the reduction and phytoavailability of chromate in mineral soil, J. Environ. Qual. 32: 120 - 128 
[6]. Cary E E, Allaway W H, Olson O E. 1977. Control of chromium concentrations in food plants. 2. Chemistry of chromium in soils and its availability to plants. J. Agric. Food. Chem., 25: $305-309$

[7]. Chandra P, Sinha S, Rai U N, 1997. Bioremediation of Cr from water and soil by vascular aquatic plants. In: Kruger E.L., Anderson T.A. and Coats J.R. (eds), Phytoremediation of Soil and Water Contaminants, ACS Symposium Series \#664, American Chemical Society, Washington, DC, pp: $274-282$

[8]. Eary LE, Rai D (1991) Chromate reduction by subsurface soils under acidic conditions. Soil Sci. Soc. Am. J., 55 : 676 - 683

[9]. Fan H, Anderson P (2005) Copper and cadmium removal by Mn oxide-coated granular activated carbon. Sep. Purif. Technol., 45 (1): $61-67$

[10]. Gueu S, Yao B, Adouby K, Ado G (2007) Kinetics and thermodynamics study of lead adsorption onto activated carbons from coconut and seed hull of the palm tree. Int. J. Environ. Sci. Tech., 4 (1): 11 - 17

[11]. Harrison LJ, May SA (1992) Bilateral subluxation of the pastern joint in the forelimbs of a foal. Vet. Rec., 131: 68 - 70

[12]. Jackson ML (1973) Soil Chemical Analysis. New Delhi: Prentice Hall of India (Pvt.). Ltd

[13]. Jha I, Iyengar L, Prabhakara Rao A (1988) Removal of cadmium using chitosan. J. Environ. Eng., 114 (4): 964 - 974

[14]. Karabulat S, Karabakan A, Denizli A, Yurum Y (2000) Batch removal of copper (II) and zinc (II) from aqueous solutions with low rank Turkish coals. Sep. Purif. Technol., 18: 177 - 184

[15]. Kentish SE, Stevens GW (2001) Innovations in separations technology for the recycling and reuse of liquid waste streams. Chem. Eng. J., 84149-59: 149 - 159

[16]. Losi ME, Amrhein C, Frankenberger WT (1994) Factors affect-ing chemical and biological reduction of Cr (VI) in soil. Environ. Toxicol. Chem., 13:1727-1735

[17]. Mahimairaja S, Bolan NS, Hedley MJ (1999) Denitrification losses of N from fresh and composted manures. Soil Biol. Biochem., 27(9): $1223-1225$

[18]. Malakootian M, Nouri J, Hossaini H (2009) Removal of heavy metals from paint industry's wastewater using Leca as an available adsorbent. Int. J. Environ. Sci. Tech., 6 (2): 183 - 190

[19]. Mathialagan T, Viraraghavan T (2002) Adsorption of cadmium from aqueous solutions by perlite. J. Hazard. Mater., 94 (3): 291 303

[20]. McBride MB (1994) Environmental Chemistry of Soils. New York: Oxford University Press, Inc

[21]. Mier MV, Callejas RL, Gehr RBE, Jimeanez Cisneros, Alvarez PJJ (2001) Heavy metal removal with Mexican clinoptilolite: Multicomponent ionic exchange. Water Res., 35 (2): 373-378

[22]. Nameni M, Moghadam MRA, Arami M (2008) Adsorption of hexavalent chromium from aqueous solutions by wheat bran. Int. J. Environ. Sci. Tech., 5 (2): $161-168$

[23]. Ross DS, Sjogren RE, Bartlett RJ (1981) Behaviour of chromium (VI) toxicity to microorganisms. J. Environ. Qual., 10 : 145 - 148

[24]. Salunkhe PB, Dhakephalkar PK, Paknikar KM (1998) Bioremediation of Hexavalent Cr in Soil Microcosms. Biotechnology Letters, 20 (8): 749 - 751

[25]. Sengupta AK, Clifford D (1986) Important process variables in chromate ion exchange. Environ. Sci. Technol., 20: 149 - 157

[26]. Tran HH, Roddick FA, O’Donell JA (1999) Comparison of chromatography and desiccant silica gels for the adsorption of metal ions-I. Adsorption and kinetics. Water Res., $33: 2992-3000$

[27]. USEPA (1979b) Method 281.4. Chromium hexavalent. In: Methods for chemical analysis of water and wastes. EPA-600/4-79-020 US EPA, Environmental Monitoring and support Laboratory, Cincinnati, $\mathrm{OH}$

[28]. Vinodhini R, Narayanan M (2008) Bioaccumulation of heavy metals in organs of fresh water fish Cyprinus earpio (Common carp). Int. J. Environ. Sci. Tech., 5 (2): 179 - 182

[29]. Walkley RB, Black IA (1934) An estimation method for determination of soil organic matter and a proposed modification of the chromic acid titration method. Soil Sci., 37: $29-33$

[30]. WHO (2004) Guidelines for Drinking-water Quality, Volume 1: Recommendations. Geneva: World Health Organization

[31]. Wingenfelder U, Nowack B, Furrer G, Schulin R (2005) Adsorption of Pb and Cd by amine-modified zeolite. Water Res., 39: 3287 $-3297$.

[32]. Zvinowanda CM, Okonkwo JO, Shabalala PN, Agyei NMA (2009) Novel adsorbent for heavy metal remediation in aqueous environments. Int. J. Environ. Sci. Tech., 6 (3): $425-434$

Table 1. Initial characteristics of soil and Poultry manure

\begin{tabular}{|l|c|c|}
\hline \multicolumn{1}{|c|}{ Parameters } & Soil & Poultry manure \\
\hline $\mathrm{pH}$ & 7.80 & 7.20 \\
\hline $\mathrm{EC}\left(\mathrm{dsm}^{-1}\right)$ & 0.36 & 1.45 \\
\hline Organic Carbon (\%) & 0.98 & 19.00 \\
\hline Avail. N $\left(\mathrm{kg} \mathrm{ha}^{-1}\right)$ & 72.80 & \\
\hline Avail. P $\left(\mathrm{kg} \mathrm{ha}^{-1}\right)$ & 14.07 & \\
\hline Avail. K $\left(\mathrm{kg} \mathrm{ha}^{-1}\right)$ & 180.00 & \\
\hline CEC $(\mathrm{m} . \mathrm{eq} / 100 \mathrm{~g})$ & 14.50 & 3.10 \\
\hline Total N (\%) & & 2.10 \\
\hline Total P $(\%)$ & & 2.80 \\
\hline Total K $(\%)$ & & \\
\hline
\end{tabular}

Table 2. Effect of poultry manure, microbial strains and earthworms on the reduction of hexavalent chromium ( $\left.\mathrm{mg} \mathrm{kg}^{-1}\right)$

\begin{tabular}{|c|c|c|c|c|c|}
\hline Treatments & Initial & $15^{\text {th }}$ day & $30^{\text {th }}$ day & $45^{\text {th }}$ day & $\begin{array}{l}60^{\text {th }} \\
\text { day }\end{array}$ \\
\hline $\mathbf{T}_{1}$-Control - Soil* & 294 & 269 & 250 & 231 & 224 \\
\hline $\mathbf{T}_{2}-$ Soil $*+$ Poultry manure & 268 & 149 & 125 & 120 & 32 \\
\hline $\mathbf{T}_{3-}$ Soil $*+$ Poultry manure + Eisenia foetida & 241 & 168 & 94 & 82 & 25 \\
\hline $\mathbf{T}_{4}-$ Soil* + Poultry manure + Eudrilus eugeniae & 240 & 149 & 104 & 56 & 44 \\
\hline $\mathbf{T}_{5}$ - Soil* + Pseudomonas fluorescens & 236 & 188 & 153 & 139 & 101 \\
\hline $\mathbf{T}_{6}-$ Soil* + Poultry manure + Pseudomonas fluorescens & 226 & 139 & 75 & 68 & 28 \\
\hline
\end{tabular}


Poultry manure induce biotransformation of hexavalent chromium in soil

\begin{tabular}{|c|c|c|c|c|c|}
\hline $\begin{array}{l}\mathbf{T}_{7} \text { - Soil } *+\text { Poultry manure }+ \text { Pseudomonas fluorescens }+ \\
\text { Eisenia foetida }\end{array}$ & 245 & 130 & 97 & 80 & 57 \\
\hline $\begin{array}{l}\mathbf{T}_{\mathbf{8}} \text { - Soil } *+\text { Poultry manure }+ \text { Pseudomonas fluorescens }+ \\
\text { Eudrilus eugeniae }\end{array}$ & 263 & 197 & 156 & 101 & 83 \\
\hline $\mathbf{T}_{9}$ - Soil $*+$ Trichoderma viride & 283 & 149 & 128 & 93 & 74 \\
\hline $\mathbf{T}_{\mathbf{1 0}}-$ Soil $*+$ Poultry manure + Trichoderma viride & 231 & 120 & 66 & 54 & 46 \\
\hline $\begin{array}{l}\mathbf{T}_{11-} \text { Soil }{ }^{*}+\text { Poultry manure + Trichoderma viride }+ \text { Eisenia } \\
\text { foetida }\end{array}$ & 298 & 135 & 100 & 82 & 65 \\
\hline $\begin{array}{l}\mathbf{T}_{12} \text { - Soil } *+\text { Poultry manure }+ \text { Trichoderma viride }+ \text { Eudrilus } \\
\text { eugeniae }\end{array}$ & 260 & 101 & 78 & 53 & 37 \\
\hline Mean & 259 & 175 & 127 & 102 & 80 \\
\hline & \multicolumn{3}{|c|}{ SEd } & \multicolumn{2}{|c|}{ CD (0.05) } \\
\hline $\mathbf{T}$ & \multicolumn{3}{|c|}{12.72} & \multicolumn{2}{|c|}{$25.36^{* *}$} \\
\hline $\mathbf{S}$ & \multirow{2}{*}{\multicolumn{3}{|c|}{7.60}} & \multicolumn{2}{|c|}{$15.16^{* *}$} \\
\hline TXS & & \multicolumn{2}{|l|}{28.43} & \multicolumn{2}{|c|}{ NS } \\
\hline
\end{tabular}

Soil* - $300 \mathrm{mg} \mathrm{Cr}(\mathrm{VI}) \mathrm{kg}^{-1}$

Table 3 Effect of poultry manure, microbial strains and earthworms on soil organic carbon $\left(\mathrm{g} \mathrm{kg}^{-1}\right)$

\begin{tabular}{|c|c|c|c|c|c|}
\hline Treatments & Initial & $15^{\text {th }}$ day & $30^{\text {th }}$ day & $45^{\text {th }}$ day & $60^{\text {th }}$ day \\
\hline $\mathbf{T}_{1}$-Control - Soil* & 9.6 & 9.2 & 7.7 & 5.6 & 4.6 \\
\hline $\mathbf{T}_{\mathbf{2}}-$ Soil $*+$ Poultry manure & 18.2 & 12.8 & 8.0 & 7.3 & 6.7 \\
\hline $\mathbf{T}_{3-}$ Soil ${ }^{*+}$ Poultry manure + Eisenia foetida & 15.2 & 11.2 & 9.8 & 5.9 & 3.5 \\
\hline $\mathbf{T}_{4}-$ Soil* + Poultry manure + Eudrilus eugeniae & 13.7 & 13.3 & 8.6 & 5.3 & 3.2 \\
\hline $\mathbf{T}_{5}-$ Soil $^{*}+$ Pseudomonas fluorescens & 8.9 & 8.4 & 5.2 & 5.2 & 4.4 \\
\hline $\mathbf{T}_{\mathbf{6}}-$ Soil $*+$ Poultry manure + Pseudomonas fluorescens & 10.7 & 12.8 & 9.3 & 5.8 & 5.5 \\
\hline $\begin{array}{l}\mathbf{T}_{7}-\text { Soil }^{*}+\text { Poultry manure }+ \text { Pseudomonas fluorescens }+ \text { Eisenia } \\
\text { foetida }\end{array}$ & 11.4 & 12.2 & 9.1 & 7.1 & 4.4 \\
\hline $\begin{array}{l}\mathbf{T}_{\mathbf{8}}-\text { Soil } *+\text { Poultry manure }+ \text { Pseudomonas fluorescens }+ \text { Eudrilus } \\
\text { eugeniae }\end{array}$ & 11.2 & 12.5 & 9.5 & 6.2 & 4.4 \\
\hline $\mathbf{T}_{9}$ - Soil* + Trichoderma viride & 12.0 & 9.7 & 7.8 & 5.6 & 4.9 \\
\hline $\mathbf{T}_{\mathbf{1 0}}-$ Soil* + Poultry manure + Trichoderma viride & 11.2 & 12.5 & 8.5 & 6.4 & 4.6 \\
\hline $\mathbf{T}_{11-}$ Soil $*+$ Poultry manure + Trichoderma viride + Eisenia foetida & 11.0 & 12.0 & 9.0 & 6.2 & 4.4 \\
\hline $\mathbf{T}_{12}-$ Soil $*+$ Poultry manure + Trichoderma viride + Eudrilus eugeniae & 12.6 & 11.8 & 8.8 & 5.0 & 5.2 \\
\hline Mean & 11.6 & 11.2 & 8.0 & 5.7 & 4.6 \\
\hline & \multicolumn{3}{|c|}{ SEd } & \multicolumn{2}{|c|}{ CD (0.05) } \\
\hline $\mathbf{T}$ & \multicolumn{3}{|c|}{0.67} & \multicolumn{2}{|c|}{$1.34 * *$} \\
\hline $\mathbf{S}$ & \multicolumn{3}{|c|}{0.40} & \multicolumn{2}{|c|}{$0.80 * *$} \\
\hline $\mathbf{T} \times \mathbf{S}$ & \multicolumn{3}{|c|}{1.50} & \multicolumn{2}{|c|}{$2.99 * *$} \\
\hline
\end{tabular}

Soil* - 300 mg Cr (VI) kg-1

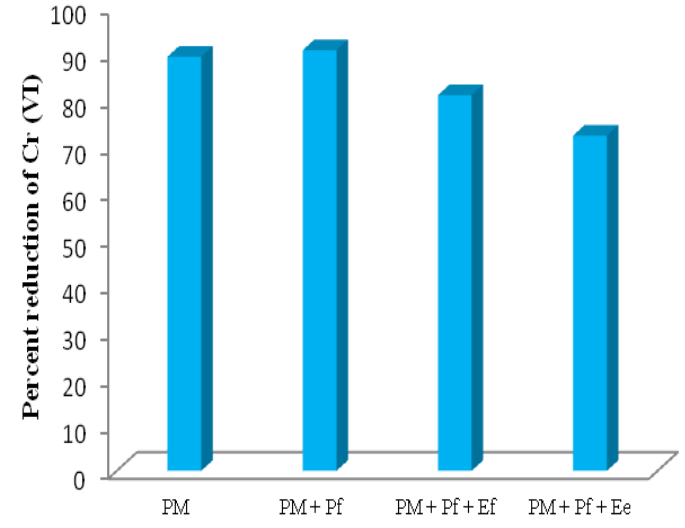

Treatments

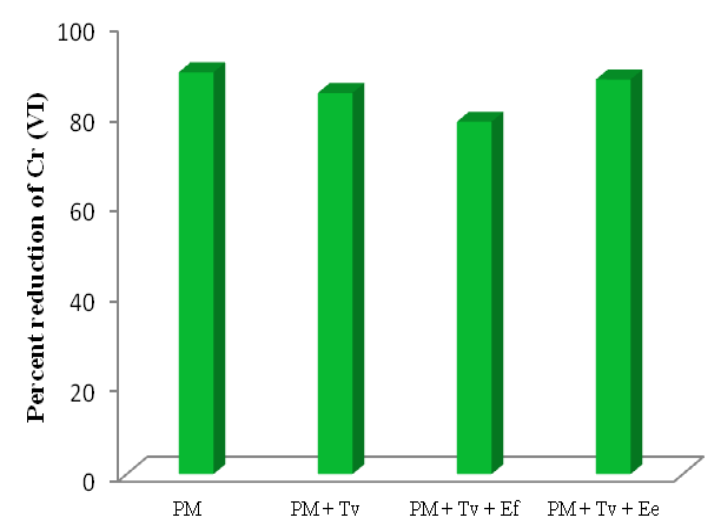

Treatments

Ef : Eisenia foetida

Ee : Eudrilus eugenia

PM : Poultry manure

Pf : Pseudomonas fluorescens

TV : Trichoderma viride

Figure 1. Percent reduction of $\mathrm{Cr}$ (VI) with poultry manure, earthworms and microbial strains 


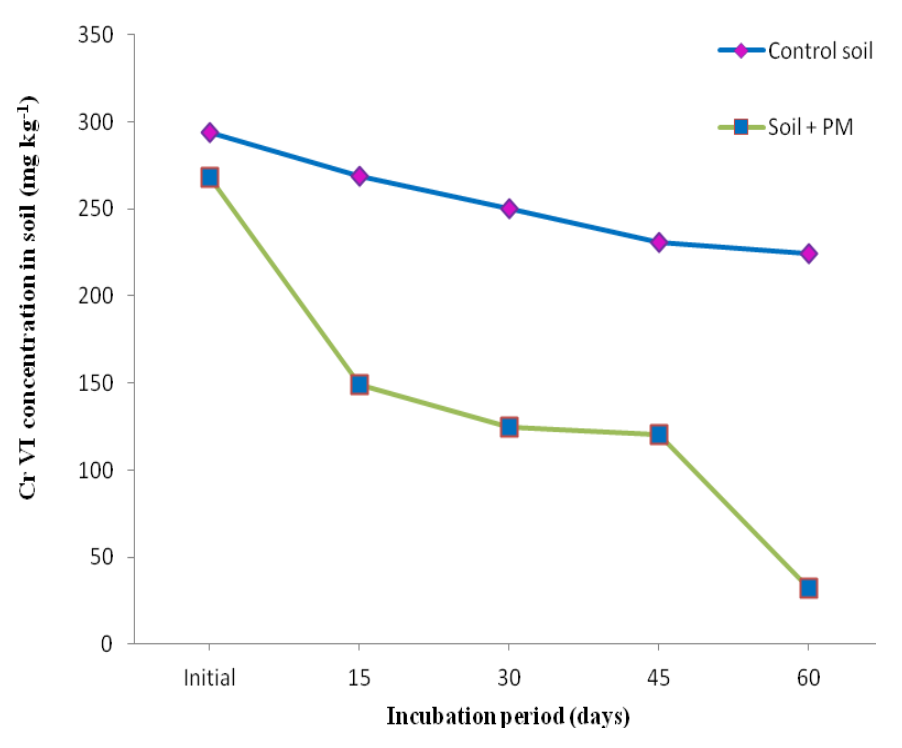

Figure 2. Effect of poultry manure on concentration of hexavalent chromium (Cr VI) in soil 